\title{
Acute hypercapnic respiratory failure in patients with chronic obstructive lung disease: risk factors and use of guidelines for management
}

\author{
Andrew A Jeffrey, Patricia M Warren, David C Flenley
}

\begin{abstract}
Background On the basis of a retrospective survey by this unit it was suggested that patients with acute ventilatory failure should be given sufficient controlled oxygen treatment to raise the arterial oxygen tension $\left(\mathrm{PaO}_{2}\right)$ to above $6.6 \mathrm{kPa}$, with the addition of a respiratory stimulant if the hydrogen ion concentration $\left(\left[\mathrm{H}^{+}\right]\right)$rose above $55 \mathrm{nmol} / 1$ and assisted ventilation if the patient remained acidotic despite these measures. This study was designed to verify the prognostic factors that determine survival in acute ventilatory failure and determine the outcome when our guidelines were implemented.
\end{abstract}

Methods One hundred and thirty nine episodes of acute hypercapnic (type II) resiratory failure were studied prospectively in 95 patients admitted with acute exacerbations of chronic obstructive lung disease. Patients had to have a $\mathrm{PaO}_{2}$ below $6.6 \mathrm{kPa}$ and an arterial carbon dioxide tension $\left(\mathrm{PaCO}_{2}\right)$ above $6.6 \mathrm{kPa}$ while breathing air.

Results The mortality associated with episodes of acute ventilatory failure was $12 \%$. Patients who died tended to be older and were significantly more acidotic, hypotensive, and uraemic on admission than those who survived, but they had similar degrees of hypoxaemia and hypercapnia. Death occurred in 10 of the 39 episodes in which arterial $\left[\mathrm{H}^{+}\right]$rose to 55 nmol/1 or above, compared with seven of the 100 episodes in which it remained below $55 \mathrm{nmol} / 1$. The respiratory stimulant doxapram was used in 37 episodes and was associated with a reduction in $\left[\mathrm{H}^{+}\right]$below $55 \mathrm{nmol} / 1$ within 24 hours in 23 episodes. Assisted ventilation was used in only four episodes.

Conclusion Arterial $\left[\mathrm{H}^{+}\right]$is an important prognostic factor for survival. Most patients treated according to the guidelines outlined above can be managed successfully without assisted ventilation.

Although patients with chronic obstructive lung disease are frequently admitted to hospital with acute exacerbations of hypercapnic respiratory failure, there is disagreement about management of this condition and a lack of well documented criteria that are easily applied at the bedside to guide intervention. The fre- quency of use of assisted ventilation in patients with acute hypercapnic respiratory failure due to chronic obstructive lung disease ${ }^{1-3}$ has varied from $16 \%$ to $35 \%$ and the overall mortality from $19 \%$ to $29 \%$. In studies combining patients with and without hypercapnia 3-65\% have been ventilated, with an overall mortality of $6-34 \% .^{4-11}$

In a retrospective study of 157 episodes of hypercapnic respiratory failure in 135 patients mortality increased with age and was highest in those with a hydrogen ion concentration $\left[\mathrm{H}^{+}\right]$ of $55 \mathrm{nmol} / 1$ or more. ${ }^{3}$ We suggested that supplemental oxygen treatment in these patients should be guided by the arterial oxygen tension $\left(\mathrm{PaO}_{2}\right)$ and $\left[\mathrm{H}^{+}\right]$and that the aim should be to increase $\mathrm{PaO}_{2}$ above $6.6 \mathrm{kPa}$ without causing the $\left[\mathrm{H}^{+}\right]$to rise to $55 \mathrm{nmol} / 1$ (fall in $\mathrm{pH}$ below 7.26). If $\left[\mathrm{H}^{+}\right]$rose higher and could not be lowered by adjustment of the inspired oxygen concentration a respiratory stimulant should be used, with assisted ventilation being reserved for patients remaining acidotic despite these measures.

To verify the previously identified prognostic factors for survival and to test the usefulness in practice of these guidelines, which were derived from data collected retrospectively, we prospectively studied 139 consecutive admissions in 95 patients suffering from acute respiratory failure due to chronic obstructive lung disease whose management was based on the guidelines.

\section{Methods}

PATIENT SELECTION

Patients were recruited from those admitted as emergency cases to the Department of Respiratory Medicine Unit at the City Hospital, Edinburgh. This was a unit with 41 beds for respiratory and general medicine cases. The nursing staff had considerable experience and skill in the care of respiratory emergencies, particularly those affecting patients with chronic obstructive lung disease, although there were no special provisions for high dependency care. All patients admitted in an acute exacerbation of chronic obstructive lung disease were included in the study if their $\mathrm{PaO}_{2}$ was less than $6.6 \mathrm{kPa}$ and their arterial carbon dioxide tension $\left(\mathrm{PaCO}_{2}\right)$ greater than $6.6 \mathrm{kPa}$ on admission when breathing room air. Patients receiving long term domiciliary oxygen treatment were included if $\mathrm{PaCO}_{2}$ exceeded $8.0 \mathrm{kPa}$ on admission when they were breathing low flow supplemental oxygen. Patients were con- 
sidered to be suffering from an exacerbation of their disease if they had been admitted because of increased cough, increased and purulent sputum production, or increased dyspnoea. They were subsequently excluded from analysis if they were later found to have an unconvincing evidence of a history of chronic obstructive lung disease or if they had radiographic evidence of a pneumothorax, bronchogenic carcinoma, pulmonary oedema, or segmental or lobar pneumonia. Patients admitted electively to the unit for assessment or respite care were not included.

CLINICAL SIGNS AND INVESTIGATIONS

Patients' history, smoking status, drug treatment, and findings on clinical examination at the time of admission were recorded on a standard proforma. If the patient was unable to give an adequate history on admission because of dyspnoea or confusion, the information was obtained from a close relative or from the patient after recovery. A standard electrocardiograph and anteroposterior chest radiograph were obtained in all patients at the time of admission. Details of treatment and clinical state were recorded at the same time as arterial blood gas tensions.

\section{MANAGEMENT}

All patients were treated initially with controlled oxygen treatment (1-2 1/min by nasal cannulae or $24-28 \%$ by Venturi mask). The dose of oxygen was adjusted to raise $\mathrm{PaO}_{2}$ above $6.6 \mathrm{kPa}$. If at any time during controlled oxygen treatment $\left[\mathrm{H}^{+}\right]$rose to $55 \mathrm{nmol} / 1(\mathrm{pH}$ below $7 \cdot 26$ ), a continuous infusion of doxapram (2 $\mathrm{mg} / \mathrm{min}$ intravenously) was started. Progress during doxapram infusion was monitored by measuring blood gas tensions two hours after the start of doxapram and thereafter every 6-8 hours. The infusion was continued for 24 hours. If by this time $\left[\mathrm{H}^{+}\right]$had fallen below 55 $\mathrm{nmol} / \mathrm{l}$ the doxapram infusion was gradually reduced and arterial blood gas tensions and $\left[\mathrm{H}^{+}\right]$continually monitored. Doxapram treatment was discontinued only when these values were within the defined guidelines. If $\left[\mathrm{H}^{+}\right]$did not fall below $55 \mathrm{nmol} / \mathrm{l}$ within 24 hours of starting doxapram treatment, or if there was a sudden deterioration in the clinical state of the patient, the decision was made whether to use assisted ventilation, taking into account the expressed wishes of the patient and his or her next of kin. Other management (antibiotic and bronchodilator treatment, physiotherapy) was left to the discretion of the responsible physician.

ARTERIAL BLOOD GAS TENSIONS AND $\left[\mathrm{H}^{+}\right]$

Arterial blood samples for gas tensions and $\left[\mathrm{H}^{+}\right]$were obtained by direct puncture of the brachial artery. Samples were stored on ice and analysed in triplicate within 10 minutes of sampling with a Radiometer ABL II automatic gas analyser. The electrodes were calibrated automatically every two hours with high and low $\mathrm{pH}$ buffer solutions and oxygen and carbon dioxide mixtures prepared by the analyser from primary gases. In addition, the analyser was calibrated manually twice weekly against blood tonometered with gas mixtures of known oxygen and carbon dioxide tension.

Arterial blood gas tensions and $\left[\mathrm{H}^{+}\right]$were measured on admission, at 1-2 and 8-12 hours after starting supplemental oxygen treatment, and on days 2 and 3 after admission. Additional measurements were made when clinically indicated, particularly to monitor the response to respiratory stimulant treatment, as described above. Arterial blood gas tensions and $\left[\mathrm{H}^{+}\right]$were also measured before discharge with the patient breathing room air or the same level of supplemental oxygen as at admission. In some episodes predischarge values were not obtained and measurements were made when the patient attended the outpatient clinic after discharge.

\section{HAEMATOLOGY AND BLOOD BIOCHEMISTRY}

Venous blood was sampled on admission, on days 2 and 3 after admission, and before discharge. Samples were analysed for haemoglobin concentration, white cell count, and urea, electrolyte, and liver enzyme concentrations.
Figure 1 Distribution of arterial $\mathrm{PO}_{2}, \mathrm{PCO}_{2}$, and $\mathrm{H}^{+}$lon admission in 123 episodes with the patient breathing air.
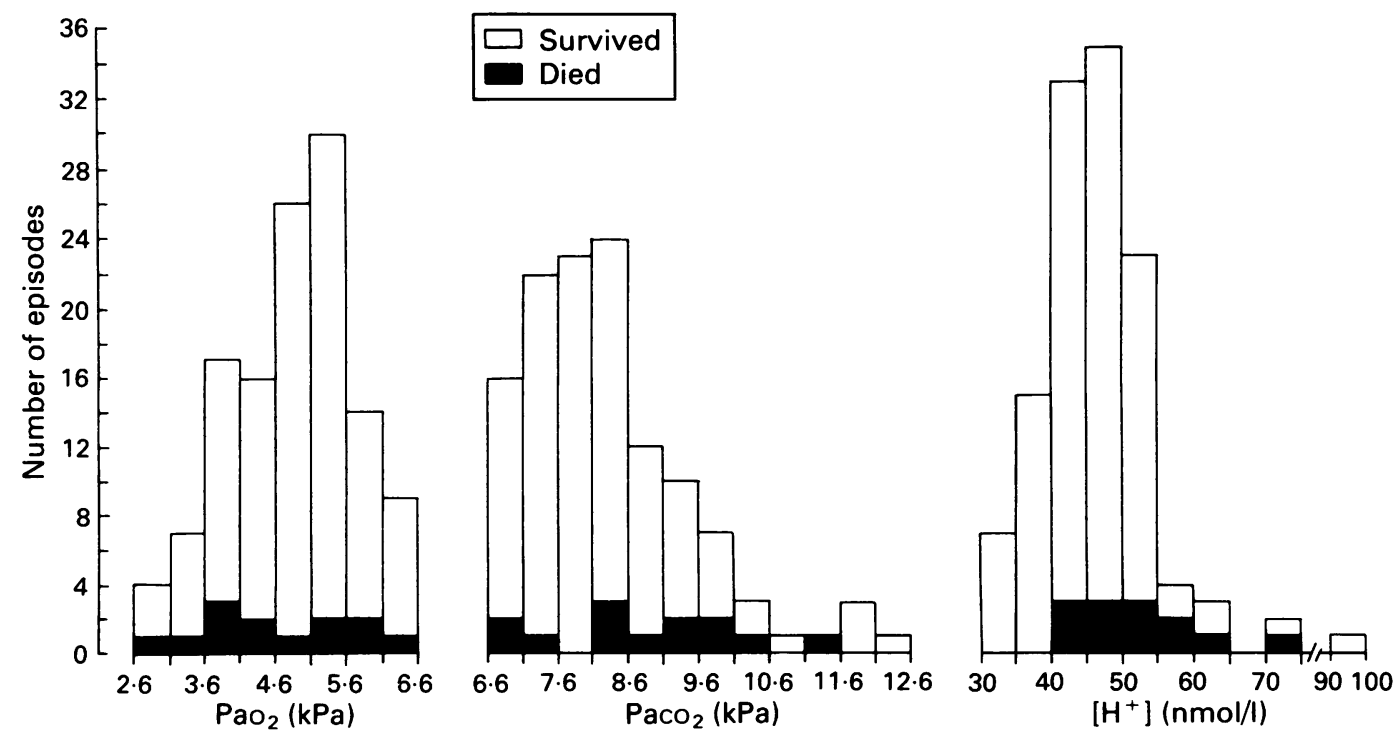

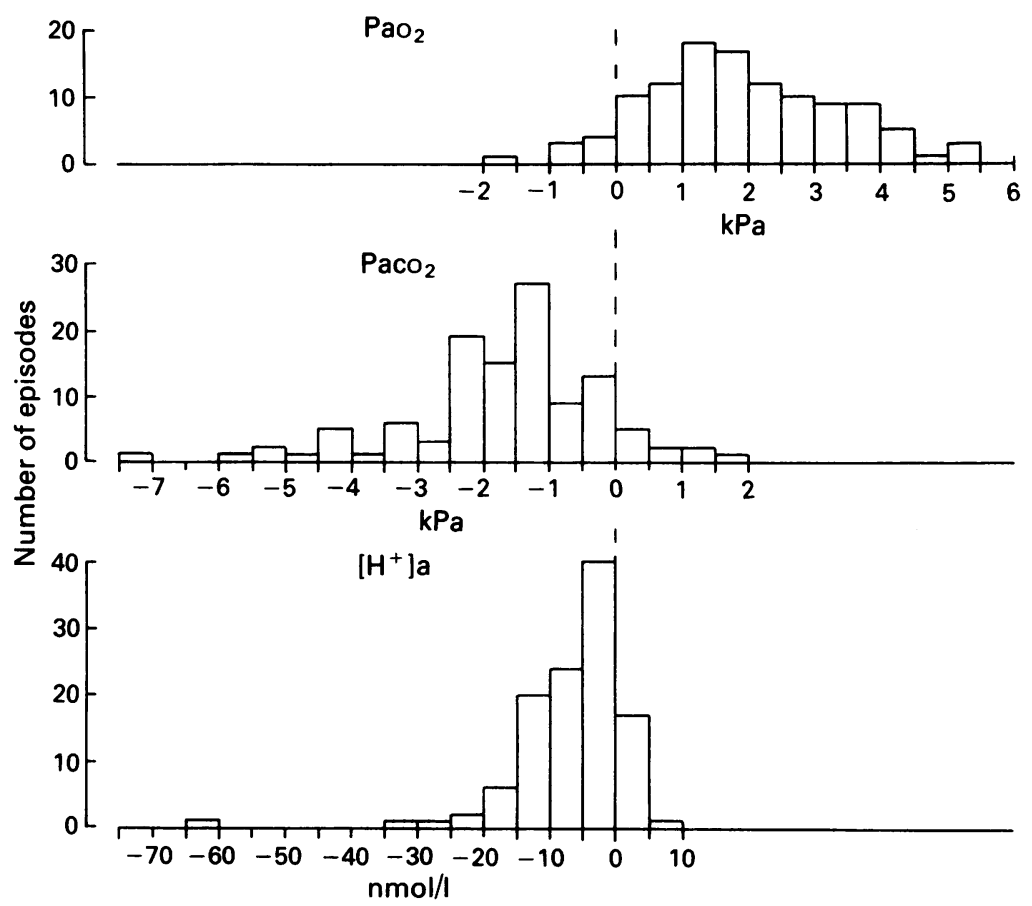

Figure 2 Values on discharge or follow up minus values on admission for arterial blood gas tensions and $\left[\mathrm{H}^{+}\right]$in 113 episodes. The positive values for $\mathrm{PaO}_{2}$ and negative values for $\mathrm{PaCO}_{2}$ and $\left[\mathrm{H}^{+}\right]$suggest that a deterioration in blood gas tensions and $\left[\mathrm{H}^{+}\right]$had occurred before admission in most episodes.

\section{STATISTICAL ANALYSIS}

The results are given as means (SD) or medians and ranges. Variables shown to be normally distributed (age; sodium, potassium, and haemoglobin concentrations; white cell count; blood pressure; arterial blood gas tensions; and $\left[\mathrm{H}^{+}\right]$other than on admission) were compared by Student's $t$ test for unpaired data. ${ }^{12}$ Data that were not normally distributed were compared with Wilcoxon's rank sum test ${ }^{12}$ for continuous variables $\left(\mathrm{PaO}_{2}, \mathrm{PaCO}_{2},\left[\mathrm{H}^{+}\right]\right.$, liver function test results, and urea concentration on admission) or the $\chi^{2}$ test with Yates' correction for discontinuous variables ${ }^{12}$ (use of hypnotics, respiratory stimulants, presence of raised jugular venous pressure or right ventricular hypertrophy, and death rate).

\section{Results}

PATIENTS AND DATA ON ADMISSION

Ninety five patients ( 55 men, 40 women) with chronic obstructive lung disease aged $63.9(7 \cdot 9)$ years were admitted for 139 episodes of type II respiratory failure. The patients reported chronic cough and sputum production for a median time of 12.5 years (range 2-40 years) before the study; 53 were current smokers, 34 were ex-smokers, and eight denied ever having smoked cigarettes. Before admission hypnotic drugs had been taken in $11 \%$ of the episodes; in all of these benzodiazepine had been taken as a sedative at night in standard dosage.

On admission, in the 123 episodes in which measurements were made while the patient breathed room air, median $\mathrm{PaO}_{2}$ was $5.0 \mathrm{kPa}$ (range 2.8 -6.5 kPa), $\mathrm{PaCO}_{2} 8 \cdot 1 \mathrm{kPa}$ (range 6.4 $12 \cdot 2 \mathrm{kPa}$ ), and $\left[\mathrm{H}^{+}\right] 45 \mathrm{nmol} / 1$ (range 31-95 nmol $\mathrm{l}^{-1}$ ), with the distributions shown in figure 1. In 16 episodes in which the patients were receiving supplemental oxygen on admission the median $\mathrm{PaO}_{2}$ was $6.2 \mathrm{kPa}$ (range 3.9-12.9 $\mathrm{kPa}$ ), $\mathrm{PaCO}_{2} 11 \cdot 1 \mathrm{kPa}$ (range $7 \cdot 2-13 \cdot 1 \mathrm{kPa}$ ), and $\left[\mathrm{H}^{+}\right] 52 \mathrm{nmol} / 1$ (range $39-65 \mathrm{nmol} / \mathrm{l}$ ).

Measurements were obtained before discharge or at follow up with the patients breathing room air in 102 episodes. The mean $\mathrm{PaO}_{2}$ was $7 \cdot 1(1 \cdot 3) \mathrm{kPa}, \mathrm{PaCO}_{2} 6 \cdot 6(1 \cdot 1) \mathrm{kPa}$, and $\left[\mathrm{H}^{+}\right]$ 40 (4) $\mathrm{nmol} / \mathrm{l}$. In a further 11 episodes in which measurements were made with the patients receiving the same degree of supplemental oxygen as on admission the mean $\mathrm{Po}_{2}$ was 8.0 (2.1) $\mathrm{kPa}, \mathrm{PaCO}_{2} 7.6(1 \cdot 5) \mathrm{kPa}$, and $\left[\mathrm{H}^{+}\right] 41$ (5) nmol/1. For all measurements combined $\mathrm{PaO}_{2}$ was on average $2 \mathrm{kPa}$ higher, $\mathrm{PaCO}_{2} 1.6 \mathrm{kPa}$ lower, and $\left[\mathrm{H}^{+}\right] 7 \mathrm{nmol} / 1$ lower before discharge or at follow up compared with admission (figure 2). Although there was no improvement in $\mathrm{PaCO}_{2}$ at discharge or follow up in 10 episodes (figure 2), eight of these showed an improvement in $\mathrm{PaO}_{2}$.

Table 1 Arterial blood gas tensions during the breathing of air, haematological results, and clinical details on admission in patients with chronic obstructive lung disease

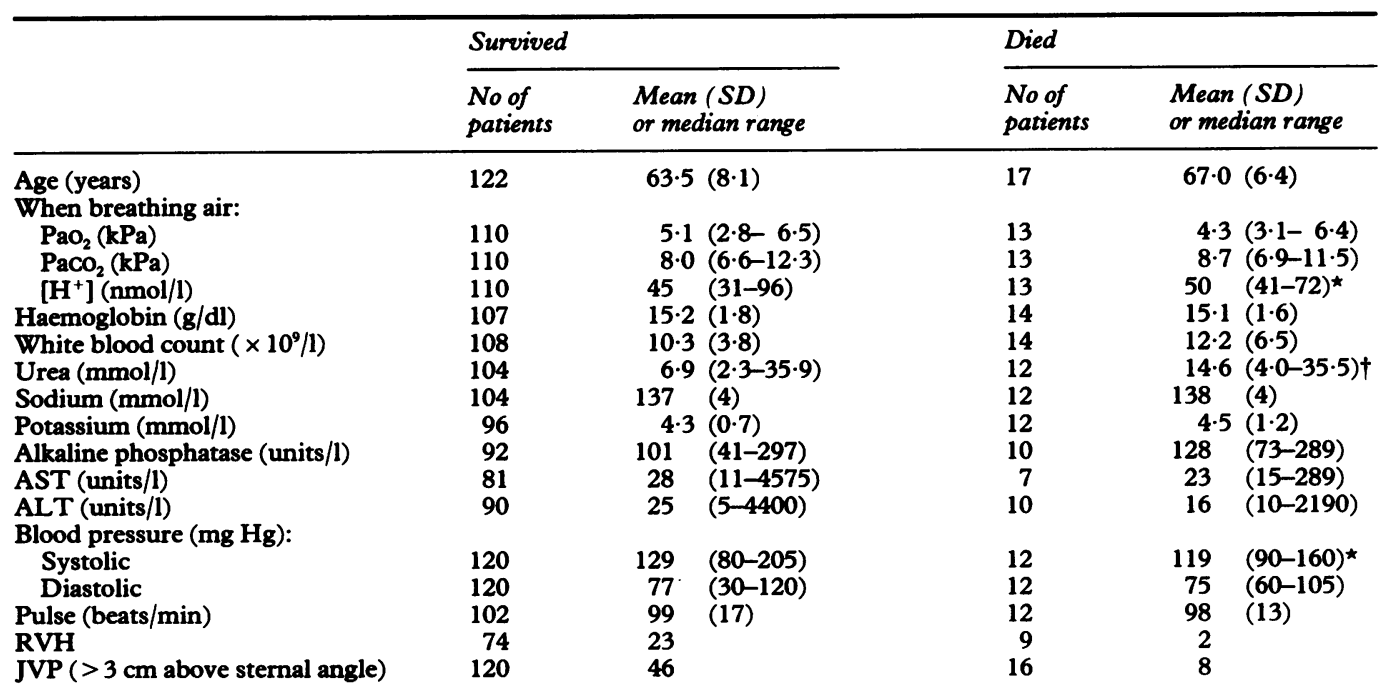

AST = aspartate aminotransferase; ALT = alanine aminotransferase; RVH = right ventricular hypertrophy; JVP = jugular venous pressure.

${ }^{\star} \mathrm{p}<0.05$. $\mathrm{tp}<0.02$. 
A raised jugular venous pressure $(>3 \mathrm{~cm}$ above the sternal angle) was recorded in 54 episodes (39\%) and peripheral "flap" in 35 episodes on admission, but papilloedema was not observed in any episodes. Electrocardiographs were taken on admission in 83 cases, and $25(30 \%)$ showed right ventricular hypertrophy (right axis deviation and $R$ wave in V1 plus $S$ wave in $V 6>10 \mathrm{~mm}$ ).

PROGNOSTIC FACTORS FOR SURVIVAL

In 17 of the 139 episodes $(12 \%)$ the patient died. The death rate in patients receiving supplemental oxygen before admission (four deaths in 16 episodes) was not significantly different from that in patients who were not ( 13 deaths in 123 episodes). The results for all 139 episodes were therefore combined for analysis except for arterial blood gas tensions and $\left[\mathrm{H}^{+}\right]$ on admission.

Patients who died during the admission tended to be older than those who survived (table 1), but the difference was not significant. There was no relation between survival and $\mathrm{PaO}_{2}$ or $\mathrm{PaCO}_{2}$ on admission when breathing room air or haematological variables, plasma electrolyte values, and liver enzyme concentrations measured on admission (table 1). The incidence of right ventricular hypertrophy and a raised jugular venous pressure were also similar in those who survived and those who died (table 1). Patients who died were, however, significantly more acidotic (figure 3 ) and uraemic and had a lower systolic blood pressure on admission than those who survived (table 1).

Controlled oxygen treatment raised $\mathrm{PaO}_{2}$ above $6.6 \mathrm{kPa}$ in 126 of the 139 episodes within 12 hours of admission. In the 126 episodes inspired oxygen was adjusted so that $\mathrm{PaO}_{2}$ was maintained between $6.6 \mathrm{kPa}$ and a mean highest value of $8.8(1.3) \mathrm{kPa}$ (range $6.6-12.3 \mathrm{kPa}$ ). There was no significant relation between $\mathrm{PaO}_{2}$ or $\mathrm{PaCO}_{2}$ at any time during the admission and survival.
Outcome was related to the severity of acidosis during the admission. Mortality was greater for episodes in which $\left[\mathrm{H}^{+}\right]$rose above $55 \mathrm{nmol} / \mathrm{l}$ ( $\mathrm{pH}$ below 7.26; figure 3). Death occurred in 10 of the 39 episodes in which the highest recorded $\left[\mathrm{H}^{+}\right]$was equal or greater than $55 \mathrm{nmol} / 1(26 \%)$ compared with seven of the 100 episodes in which $\left[\mathrm{H}^{+}\right]$remained below $55 \mathrm{nmol} / 1$ ( $\mathrm{p}<0.05$ ). The best discriminator of the likelihood of death on retrospective analysis was a highest recorded $\left[\mathrm{H}^{+}\right]$of greater than $53 \mathrm{nmol} / 1 \quad(\mathrm{pH}<7.28) \quad(\mathrm{p}<0.001)$. Death occurred in 13 out of 46 such episodes (28\%) compared with only four out of 93 episodes $(4 \%)$ in which $\left[\mathrm{H}^{+}\right]$remained below $53 \mathrm{nmol} / 1$. Although the mortality was related to the highest degree of acidosis recorded, the highest $\left[\mathrm{H}^{+}\right]$was recorded immediately before death in only four of the fatal episodes. In 101 episodes $(73 \%)$ the highest $\left[\mathrm{H}^{+}\right]$was recorded within eight hours of admission.

\section{USE OF A RESPIRATORY STIMULANT}

Doxapram ( $2 \mathrm{mg} / \mathrm{min}$ intravenously) was given in 37 episodes $(27 \%)$ for between one and five days. The criterion for the use of respiratory stimulants (see methods) was not always adhered to (table 2). A maximum $\left[\mathrm{H}^{+}\right]$of 55 $\mathrm{nmol} / \mathrm{l}$ or above was recorded in 39 episodes. In four of these episodes a reduction of inspired oxygen from 2 to $1 \mathrm{l} / \mathrm{min}(\mathrm{n}=3)$ or from $28 \%$ to $24 \%(n=1)$ was accompanied by a fall in $\mathrm{PaCO}_{2}$ and $\left[\mathrm{H}^{+}\right]$while adequate arterial oxygenation was maintained $\left(\mathrm{PaO}_{2}>6.6 \mathrm{kPa}\right)$; in two further episodes the high $\left[\mathrm{H}^{+}\right]$and $\mathrm{PaCO}_{2}$ recorded on admission fell within two hours of starting oxygen treatment. One patient died suddenly before treatment could be started and one patient was ventilated without a trial of doxapram because of a sudden and dramatic deterioration in clinical state. Four patients did not receive doxapram although eligible, the maximum recorded $\left[\mathrm{H}^{+}\right]$in this group being $56 \mathrm{nmol} / \mathrm{l}$. Thus doxapram was given in 27 of
Figure 3 Relation between outcome of the episode and acid-base state on admission when patients were breathing room air and at the highest recorded and at the highest recorded
$\left[\mathrm{H}^{+}\right]$during the episode. Acid-base state is plotted on an $\left[\mathrm{H}^{+}\right] / \mathrm{PCO}_{2}$ diagram ${ }^{13}$ with the dashed lines indicating the $95 \%$ confidence limits for the normal $\left[\mathrm{H}^{+}\right] / \mathrm{PCO}_{2}$ relation (denoted by the square) and the four basic disturbances of acid-base state (respiratory acidosis and alkalosis, metabolic acidosis and alkalosis) for arterial blood in vivo. Each point represents the acid-base state in a single episode. The dotted horizontal line in the right hand panel indicates an $\left[\mathrm{H}^{+}\right]$concentration of $55 \mathrm{nmol} / \mathrm{l}$.

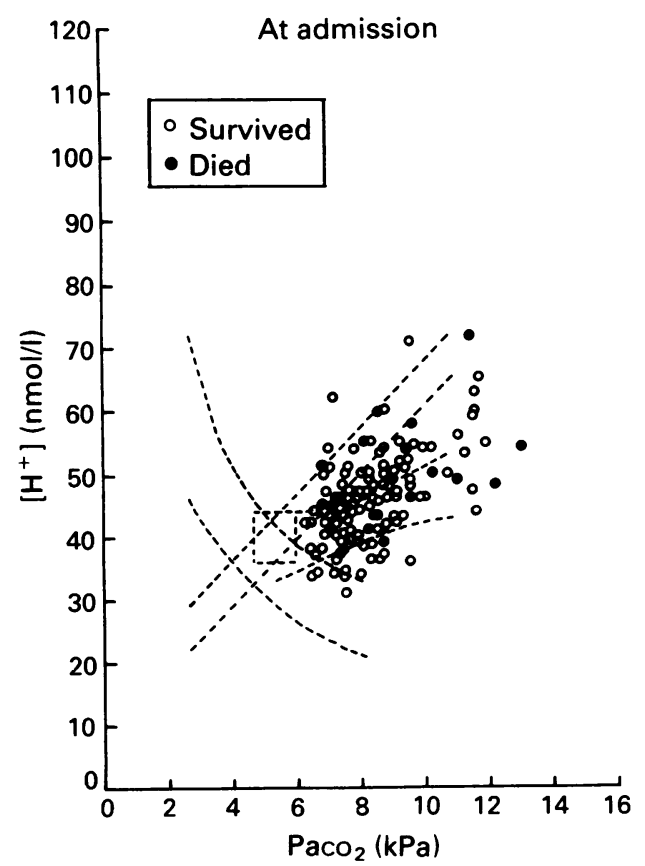


Table 2 Summary of treatment and outcome in relation to maximum $\left[\mathrm{H}^{+}\right]$recorded in an episode

\begin{tabular}{|c|c|c|c|}
\hline & $\begin{array}{l}\text { No of } \\
\text { patients }\end{array}$ & Survived & Died \\
\hline \multicolumn{4}{|c|}{ Maximum recorded $\left[\mathrm{H}^{+}\right] \geqslant 55 \mathrm{nmol} / \mathrm{l}(\mathrm{n}=39)$} \\
\hline \multicolumn{4}{|l|}{$\left[\mathrm{H}^{+}\right]$fall } \\
\hline With decrease in $\mathrm{O}_{2}$ & 4 & 4 & $\mathbf{0}$ \\
\hline With rise in $\mathrm{O}_{2}$ & 2 & 2 & 0 \\
\hline \multicolumn{4}{|l|}{ Doxapram: } \\
\hline \multicolumn{4}{|l|}{ No trial: } \\
\hline Died suddenly & 1 & 0 & 1 \\
\hline Ventilated & 1 & 1 & 0 \\
\hline Given (number ventilated) & 27 (3) & (3) & (0) \\
\hline None, no reason recorded & 4 & 4 & 0 \\
\hline \multicolumn{4}{|c|}{ Maximum recorded $\left[\mathrm{H}^{+}\right]<55 \mathrm{nmol} / \mathrm{l}(\mathrm{n}=100)$} \\
\hline Doxapram: & & & \\
\hline None & 90 & 85 & 5 \\
\hline Given & 10 & 6 & 4 \\
\hline
\end{tabular}

the 39 episodes and in addition, in 10 episodes in which arterial $\left[\mathrm{H}^{+}\right]$never rose above $55 \mathrm{nmol} / 1$ (median $\left[\mathrm{H}^{+}\right]$on starting doxapram 52 (range 46-54) nmol/1).

In 11 episodes $(30 \%)$ in which doxapram was used the patient died. Seven of the deaths occurred during doxapram treatment, but four occurred suddenly some time after arterial blood gas tensions and $\left[\mathrm{H}^{+}\right]$had improved and treatment had been stopped. In three episodes assisted ventilation was added as $\left[\mathrm{H}^{+}\right]$had not fallen below $55 \mathrm{nmol} / 124$ hours after starting doxapram treatment. There was no significant difference between arterial blood gas tensions and $\left[\mathrm{H}^{+}\right]$before doxapram treatment in the 23 episodes in which the patient survived compared with the 14 episodes in which assisted ventilation was required or which ended in death (table 3). Doxapram infusion was associated with a fall in $\mathrm{PaCO}_{2}$ and $\left[\mathrm{H}^{+}\right]$within 24 hours of starting treatment in the patients who survived. Both variables deteriorated over this period in the ventilated and fatal episodes with mean $\left[\mathrm{H}^{+}\right]$significantly higher after $12-18$ hours of doxapram treatment compared with the episodes in which the patients survived $(p<0.05)$ (table 3). Doxapram infusion frequently caused agitation but adverse side effects never necessitated stopping treatment.

USE OF ASSISTED VENTILATION

Assisted ventilation was used in three of the eight episodes in which doxapram did not lower $\left[\mathrm{H}^{+}\right]$below $55 \mathrm{nmol} / 1$ within 24 hours. In the five other episodes the decision not to ventilate the patient was taken on clinical grounds; four patients died. The fourth patient was intubated without receiving doxapram owing to sudden deterioration in clinical state. All four patients who were ventilated survived the episode.

BRONCHODILATOR AND ANTIBIOTIC TREATMENT

Information on bronchodilator treatment was recorded in 130 episodes. In 123 of these $\beta_{2}$ agonists were given within $36-48$ hours of admission and one episode was treated with aminophylline. No reasons were recorded for witholding bronchodilators in the other episodes. An antibiotic was prescribed in 120 cases (oral ampicillin in 99 episodes). No intravenous steroid treatment was used. Preadmission oral steroid treatment was continued in $30 \%$ of episodes but only to a maximum of $20 \mathrm{mg} /$ day of prednisone. Mortality did not differ between those who received bronchodilators and those who did not, or between those who did and did not receive steroids (3/42 episodes treated with steroids $v 14 / 97$ episodes that were not).

\section{Discussion}

This study had two aims. The first was to verify the prognostic factors for survival in patients with acute hypercapnic respiratory failure due to chronic obstructive lung disease previously identified in a retrospective study. The second was to test whether the bedside guidelines for treatment in these patients derived from retrospective data ${ }^{3}$ were useful in clinical practice.

Inclusion of patients in the study was based on arterial blood gas tensions. Acute exacerbations of the disease were identified when there were reported increases in cough, purulent sputum production, and dyspnoea. The lower $\mathrm{PaO}_{2}$ and higher $\mathrm{PaCO}_{2}$ values on admission compared with those before discharge or at follow up support the clinical evidence that the patients had an acute exacerbation of their chronic condition.

The results confirm the relation between a high arterial $\left[\mathrm{H}^{+}\right]$(low arterial $\mathrm{pH}$ ) and increased mortality. ${ }^{2-49}$ As in our earlier study, ${ }^{3}$

Table 3 Arterial blood gas tensions and $\left[\mathrm{H}^{+}\right]$immediately before and during the first 48 hours of treatment with doxapram

\begin{tabular}{|c|c|c|c|c|c|}
\hline Doxapram (h) & Outcome & $\begin{array}{l}\text { No of } \\
\text { episodes }\end{array}$ & $\mathrm{PaO}_{2}(\mathrm{kPa})$ & $\mathrm{PaCO}_{2}(\mathrm{kPa})$ & {$\left[\mathrm{H}^{+}\right](\mathrm{nmol} / \mathrm{l})$} \\
\hline Before & $\left\{\begin{array}{l}\text { Survived } \\
\text { Died }\end{array}\right.$ & $\begin{array}{l}23 \\
14\end{array}$ & $\begin{array}{ll}6 \cdot 5 & (2 \cdot 0) \\
5 \cdot 7 & (1 \cdot 8)\end{array}$ & $\begin{array}{ll}10 \cdot 6 & (1 \cdot 7) \\
10 \cdot 1 & (1 \cdot 2)\end{array}$ & $\begin{array}{ll}56 & (5) \\
55 & (8)\end{array}$ \\
\hline $0-6$ & $\begin{array}{l}\text { Survived } \\
\text { Died }\end{array}$ & $\begin{array}{l}17 \\
11\end{array}$ & $\begin{array}{ll}7 \cdot 1 & (1 \cdot 8) \\
6 \cdot 6 & (1 \cdot 8)\end{array}$ & $\begin{array}{rr}9.8 & (1.5) \\
10.0 & (2.2)\end{array}$ & $\begin{array}{l}53(6) \\
53(10)\end{array}$ \\
\hline $6-12$ & $\begin{array}{l}\text { Survived } \\
\text { Died }\end{array}$ & $\begin{array}{l}15 \\
11\end{array}$ & $\begin{array}{ll}7 \cdot 8 & (4 \cdot 0) \\
7 \cdot 3 & (2 \cdot 4)\end{array}$ & $\begin{array}{ll}10 \cdot 2 & (1 \cdot 8) \\
10 \cdot 0 & (2 \cdot 3)\end{array}$ & $\begin{array}{l}49(10) \\
56 \quad(9)\end{array}$ \\
\hline $12-18$ & $\begin{array}{l}\text { Survived } \\
\text { Died }\end{array}$ & $\begin{array}{l}9 \\
5\end{array}$ & $\begin{array}{ll}7 \cdot 4 & (0 \cdot 9) \\
6 \cdot 0 & (2 \cdot 6)\end{array}$ & $\begin{aligned} 9.3 & (1.9) \\
12.5 & (3.2)\end{aligned}$ & $\begin{array}{l}43(7)^{\star} \\
63(10)\end{array}$ \\
\hline $18-24$ & $\left\{\begin{array}{l}\text { Survived } \\
\text { Died }\end{array}\right.$ & $\begin{array}{l}8 \\
6\end{array}$ & $\begin{array}{ll}7 \cdot 6 & (1.4) \\
7 \cdot 1 & (1.8)\end{array}$ & $\begin{aligned} 9 \cdot 4 & (1 \cdot 3) \\
12 \cdot 3 & (4 \cdot 1)\end{aligned}$ & $\begin{array}{ll}47(8) \\
54(13)\end{array}$ \\
\hline $24-48$ & $\left\{\begin{array}{l}\text { Survived } \\
\text { Died }\end{array}\right.$ & $\begin{array}{r}16 \\
6\end{array}$ & $\begin{array}{ll}7.5 & (0.9) \\
6.8 & (1.3)\end{array}$ & $\begin{array}{rr}9 \cdot 2 & (1 \cdot 5) \\
10 \cdot 1 & (3 \cdot 7)\end{array}$ & $\begin{array}{lr}44 & (5) \\
54 & (24)\end{array}$ \\
\hline
\end{tabular}

${ }^{\star} p<0.05$ between groups. Significant difference $(\mathrm{p}<0.05)$ in $\left[\mathrm{H}^{+}\right]$between the two groups. 
there was a significantly increased risk of death in patients in whom $\left[\mathrm{H}^{+}\right]$rose to $55 \mathrm{nmol} / 1$ or more ( $\mathrm{pH}<7.26$ ) during their stay in hospital. Retrospective analysis in this new study showed that death was more likely if $\left[\mathrm{H}^{+}\right]$rose above $53 \mathrm{nmol} / \mathrm{l}$. As $\mathrm{we}^{3}$ and others ${ }^{49}$ have shown, neither $\mathrm{PaO}_{2}$ nor $\mathrm{PaCO}_{2}$ on admission or after oxygen treatment predicted the outcome of the episode. Thus the severity of an exacerbation is indicated not by the absolute level of hypercapnia in these patients but rather by the increase above the chronic stable value of the $\mathrm{PaCO}_{2}$ as reflected in the increased acidosis.

The patients who died had significantly higher blood urea concentrations and lower systolic blood pressures on admission than those who survived, a finding also noted in patients with community acquired pneumonia. ${ }^{14}$ These findings probably reflect the severity of systemic disturbance associated with an exacerbation as there was no evidence of a significant metabolic acidosis associated with either the raised urea concentration or poor tissue perfusion (figure 3). Although previous studies by us $^{3}$ and others ${ }^{4}$ have shown an increase in death rate with age, the patients who died in the present study tended to be older than those who survived, but the difference was not significant.

The guidelines derived from the retrospective study proposed that a respiratory stimulant such as doxapram should be used if $\left[\mathrm{H}^{+}\right]$rose to $55 \mathrm{nmol} / 1$ or more while the patient was being given oxygen treatment, with assisted ventilation being considered only when this regimen failed to reduce the acidosis. These guidelines were not followed rigorously as the degree of acidosis occurred only transiently in some patients and in others respiratory stimulant treatment was believed by the attending physician to be indicated clinically before severe acidosis had developed. We combined the data from all patients who had received doxapram to allow us to study the effect of the treatment as it was used. It is not possible to prove whether systematic use of a respiratory stimulant contributed directly to the lower mortality of $12 \%$ recorded in this study compared with the rate of $20 \%$ in the retrospective series. ${ }^{3}$ An overall mortality of $30 \%$ in the 37 episodes treated with doxapram (table 2) seems high, but these patients were selected for doxapram treatment because they had severe respiratory acidosis and their risk of death was therefore high. As respiratory acidosis improved during doxapram therapy in 23 episodes and the patient survived without needing assisted ventilation, the use of a respiratory stimulant may have contributed to the lower death rate. The fall in $\left[\mathrm{H}^{+}\right]$in these 23 episodes may have been unrelated to the doxapram treatment, but the response is consistent with the effect of doxapram seen in a placebo controlled trial in similar patients. ${ }^{1}$ Although respiratory stimulants were used in a similar proportion of episodes in this study $(27 \%)$ and our retrospective series $(29 \%){ }^{3}$ many of the patients in the earlier study were given intermittent nikethamide rather than a continuous infusion of doxapram and respiratory stimu- lants tended to be used as a last resort in patients considered to be unsuitable for assisted ventilation. In the present study use of doxapram in a fairly systematic manner based on objective starting criteria may have contributed to the low mortality rate, but this is difficult to prove.

Other treatments were similar in the two studies except for the use of nebulised $\beta_{2}$ agonists in this but not the earlier series. Whether this may also have contributed to the improved survival rate, is impossible to say. Patients taking oral steroids had a slightly lower mortality, probably reflecting the fact that they had been selected, when their condition was stable, as having a slightly larger reversible component to their airways obstruction. The response of such patients in an exacerbation may differ from the response of those not taking steroids, but we cannot say whether the routine use of corticosteroids is helpful in episodes of acute ventilatory failure.

In this study, episode death rate was $12 \%$, and assisted ventilation was used in only four episodes (3\%). Mortality in previous studies has ranged from $6 \%$ to $34 \%$ and use of assisted ventilation from $3 \%$ to $65 \%{ }^{1-11}$ Direct comparison of rates between studies is difficult as the criteria for inclusion of patients has varied, objective criteria have not always been quoted, ${ }^{911}$ and not all patients have had type II respiratory failure due to chronic obstructive lung disease. ${ }^{410}$ Other studies, including our retrospective study, were restricted to patients with type II respiratory failure due to chronic obstructive lung disease and report rates of between $19 \%$ and $29 \% .^{1-3}$ The death rate in the present study is therefore lower than that previously reported in similar patients despite minimal use of assisted ventilation. Our emphasis on raising $\mathrm{PaO}_{2}$ above $6.6 \mathrm{kPa}$ with controlled low flow oxygen treatment was generally achieved and may have contributed to the successful outcome compared with our earlier study. ${ }^{3}$ However, data are insufficient on the degree of oxygenation achieved in our previous study to determine this.

In previous series the decision to ventilate has usually been taken on a clinical basis, ${ }^{2-79}$ resulting in the use of assisted ventilation in 4 $65 \%$ of episodes. Only two groups have used criteria based on $\mathrm{PaO}_{2}^{8}$ or a combination of $\mathrm{pH}$ and $\mathrm{SaO}_{2}{ }^{10}$ Our rationale for using assisted ventilation differed from that of others in that in all but one episode its use was actively considered only on the strictly objective criteria that doxapram treatment had failed to reduce acidaemia. This small group of patients were then further assessed on clinical grounds in the light of their own and their relatives' expressed wishes before the decision to ventilate was taken. Using these criteria we found that assisted ventilation was indicated in only $6 \%$ of episodes and deemed appropriate in only $3 \%$. The fact that most of these patients can be treated successfully with minimal recourse to assisted ventilation needs to be taken into account when assessing new techniques of respiratory support, such as nasal intermittent positive pressure ventilation, in the treatment 
of acute respiratory failure in chronic obstructive lung disease.

This study confirms that the degree of acidosis developed is a major factor in determining survival of patients with an acute exacerbation of type II respiratory failure due to chronic obstructive lung disease. The results provide support for the therapeutic guidelines which were derived empirically from our retrospective study. ${ }^{3}$ The results also show that these guidelines were applicable in practice and associated with a comparatively low episode mortality without recourse to assisted ventilation. Maintaining $\mathrm{PaO}_{2}$ above $6.6 \mathrm{kPa}$ with controlled oxygen treatment and using a respiratory stimulant if necessary to maintain $\left[\mathrm{H}^{+}\right]$below $55 \mathrm{nmol} / 1$ means that most patients can be treated successfully without recourse to assisted ventilation.

1 Moser KM, Luchsinger PC, Adamson JS, McMahon SM, Schlueter DP, Spivack M, et al. Respiratory stimulation with intravenous doxapram in respiratory failure. A double-blind co-operative study. $N$ Engl J Med 1973; 288:427-31.

2 Kettel LJ, Diener CF, Morse JO, Stein HF, Burrows B. Treatment of acute respiratory acidosis in chronic obstructive lung disease. $J A M A$ 1971;217:1503-8.

3 Warren PM, Flenley DC, Millar JS, Avery A. Respiratory failure revisited: acute exacerbations of chronic bronchitis between 1961-68 and 1970-76. Lancet 1980;i:467-71.

4 Asmundsson T, Kilburn KH. Survival of acute respiratory failure: a study of 239 episodes. Ann Intern Med 1969; 70:471-85.

5 Vandenbergh E, van de Woestijne KP, Gyselen A. Conservative treatment of acute respiratory failure in patients with chronic obstructive lung disease. Am Rev Respir Dis 1968;98:60-9.

6 Sluiter HJ, Blokzijl EJ, van Dijl W, van Haeringen JR, Hilvering $C$, Steenhuis EJ. Conservative and respirator treatment of acute respiratory insufficiency in patients with chronic obstructive lung disease. Am Rev Respir Dis 1972;105:932-43.

7 Burk RH, George RB. Acute respiratory failure in chronic obstructive pulmonary disease. Immediate and long-term obstructive pulmonary disease. Immediate and

8 Seriff NS, Khan F, Lazo BJ. Acute respiratory failure. Current concepts of pathophysiology and management. Med Clin N Am 1973;57:1539-50.

9 Bone RC, Pierce AK, Johnson RL. Controlled oxygen administration in acute respiratory failure in chronic obstructive pulmonary disease. Am J Med 1978;65: 896-902.

10 Martin TR, Lewis SW, Albert RK. The prognosis of patients with chronic obstructive pulmonary disease after hospitalization for acute respiratory failure. Chest 1982. 82:310-4.

11 Hanson FN, Floreani AA, Pingleton SK, Bunce SB. Usefulness of Apache II variables in predicting survival and death in COPD patients in the ICU. Am Rev Respir Dis death in (OPD patients

12 Snedecor GW, Cochran WG. Statistical methods. 6th ed. Ames: Iowa State Press, 1967.

13 Flenley DC. Interpretation of blood-gas and acid-base data. Br J Hosp Med 1978;20:384-94.

14 British Thoracic Society Research Committee. Community acquired pneumonia in adults in British Hospitals in 1982-83: a survey of aetiology, mortality, prognostic factors and outcome. $Q J$ Med 1987;62:195-220. 